\title{
Penerapan Model Pembelajaran Problem Solving Untuk Meningkatkan Kemampuan Pemecahan Masalah Matematika Siswa Sekolah Dasar
}

\author{
Citra Maesari ${ }^{1}$, Rusdial Marta ${ }^{2}$, Yusnira $^{3}$ \\ Program Studi Pendidikan Guru Sekolah Dasar \\ Fakultas Ilmu Pendidikan \\ Universitas Pahlawan Tuanku Tambusai \\ Email penulis: citramaesari@gmil.com
}

\begin{abstract}
Abstrak
Penelitian ini bertujuan untuk meningkatkan kemampuan pemecahan masalah matematika siswa kelas IV SDN 004 Bangkinang Kota dengan menggunakan model pembelajaran Problem Solving pada materi operasi hitung bilangan cacah. Subjek penelitian ini adalah siswa kelas IV SDN 004 Bangkinang Kota tahun ajaran 2019/2020 yang berjumlah 12 orang siswa. Jenis penelitian ini adalah penelitian tindakan kelas yang dilaksanakan 2 siklus, masing-masing siklus dilaksanakan 2 kali pertemuan. Pengambilan data dilakukan dengan tes kemampuan pemecahan masalah, lembar observasi guru, dan siswa sebagai tingkat keterlaksanaan dan pencapaian dalam menggunakan model pembelajaran Problem Solving. Hasil kemampuan pemecahan masalah dapat dilihat dari hasil tes prasiklus, siklus I dan siklus II. Pada tes prasiklus nilai rata-rata 59,16 dengan persentase ketuntasan belajar $25 \%$, pada siklus 1 pertemuan I mengalami peningkatan dengan nilai rata-rata siswa 63,5 dengan persentase ketuntasan belajar 33,33\% dan pada siklus 1 pertemuan II mengalami peningkatan juga dengan nilai rata-rata 70,16 dengan persentase ketuntasan belajar $58,33 \%$. Pada siklus 2 pertemuan I mengalami peningkatan dengan nilai rata-rata 76,00 dengan persentase ketuntasan belajar 75\%, dan pada siklus 2 pertemuan II mengalami peningkatan dengan nilai rata-rata 84,66 dengan persentase ketuntasan belajar 83,33\%. Berdasarkan hasil penelitian dapat disimpulkan bahwa model pembelajaran Problem Solving dapat meningkatkan kemampuan pemecahan masalah matematika siswa pada materi operasi hitung bilangan cacah di kelas IV SD Negeri 004 Bangkinang Kota.
\end{abstract}

Kata kunci : Kemampuan Pemecahan Masalah, Model Pembelajaran Problem Solving, Matematika

Abstract
This research is aimed at improving mathematical problem solving competency of the
fourth grade students at SDN 004 Bangkinang Kota by implementing problem solving
learning model on mathematical operation material on whole number. The subjects of this
research are the fourth grade students of SDN 004 Bangkinang Kota in the academic year
$2019 / 2020,12$ students. This is Classroom Action Research which is carried out in 2
cycles, each cycles consist of 2 meeting. The date were obtained by administering
problem solving questions, observing teachers and students activities to find out the
students achievement through problem solving learning model. The findings of problem
solving competency are obtained from the result of the pre-cycle test, cycle 1 cycle 2 . In
the pre cycle test the average score of the students were 59,16 with the learning
achievement percentages of $25 \%$. In the cycle 1 first meeting, there was an in increase of 
the average student score is 63,5 with the learning achievement percentages of $33,33 \%$, and in the cycle 1 meeting second there was an increase of the average student score is 70,16 with the learning achievement percentages $58,33 \%$. \%. In the cycle 2 first meeting, there was an in increase of the average student score is 76,00 with the learning achievement percentages of $75 \%$, and in the cycle 2 meeting second there was an increase of the average student score is 84,66 with the learning achievement percentages $83,33 \%$. The findings showed that problem solving learning model is able to improve the mathematical problem solving competency elementary school students on operation count whole number material of grade IV SDN Bangkinang Kota.

\section{Keywords: Problem Solving Competency, Problem Solving Learning Model, Mathematics}

\section{PENDAHULUAN}

Matematika adalah mata pelajaran pokok yang ada di setiap jenjang pendidikan. Hal tersebut dirumuskan dalam permendiknas nomor 22 Tahun 2006, yang mengatakan bahwa mata pelajaran matematika perlu diberikan di setiap jenjang pendidikan untuk membekali peserta didik dengan kemampuan berpikir logis, kritis, analitis, sistematis, dan kreatif serta kemampuan bekerja sama. Matematika mempunyai peran penting dalam berbagai disiplin ilmu dalam mengembangkan daya pikir manusia, dengan mempelajari matematika siswa lebih kritis dalam memahami suatu permasalahan dalam kehidupan seharihari. Oleh sebab itu, pelajaran matematika perlu diberikan kepada semua siswa mulai dari Sekolah Dasar (SD) sampai ke perguruan tinggi. Matematika merupakan ilmu universal yang mampu memberi peluang bagi terbentuknya kemampuan berkomunikasi, berfikir, memecahkan masalah dan bernalar bagi siswa.

Menurut Permendikbud Nomor

58 Tahun 2014 dijelaskan bahwa mata pelajaran matematika bertujuan agar siswa mampu: (1) memahami konsep matematika; (2) memecahkan masalah; (3) menggunakan penalaran matematis; (4) mengomunikasikan masalah secara sistematis; dan (5) memiliki sikap dan perilaku yang sesuai dengan nilai dalam matematika. Sejalan dengan National Council of Teachers of Mathematics (dikutip oleh Sari, 2017) juga merumuskan tujuan pembelajaran matematika terdiri dari lima kemampuan dasar matematika yang merupakan standar yakni pemecahan masalah (Problem Solving), penalaran dan bukti (reasoning and proof), komunikasi (communication), koneksi (connections), dan representasi (representation).

Berdasarkan tujuan di atas yang menjadi fokus penting di dalam pembelajaran matematika di SD adalah pemecahan masalah, seperti yang disebut Cockroft (Ismawati, 2014: 2) menyatakan bahwa: Matematika perlu diajarkan kepada siswa karena (1) selalu digunakan dalam segi kehidupan; (2) semua bidang studi memerlukan matematika yang sesuai; (3) merupakan sarana komunikasi yang kuat, singkat dan jelas; (4) dapat digunakan untuk menyajikan informasi dalam berbagai cara; (5) meningkatkan kemampuan berpikir logis, ketelitian, dan kesadaran ruangan, dan (6) memberikan kepuasan terhadap usaha memecahkan masalah.

Bitter dan Capper (Asmariana, 2013: 2) menyatakan bahwa "Pengajaran matematika harus digunakan untuk memperkaya, memperdalam, dan memperluas kemampuan siswa dalam pemecahan masalah matematika". Ismawati (2014: 3) menyatakan bahwa "kemampuan pemecahan masalah sangat penting, bukan saja bagi mereka yang kemudian hari akan mendalami matematika, melainkan juga bagi mereka yang akan 
menerapkannya dalam bidang studi lain maupun kehidupan sehari-hari".

Berdasarkan hasil observasi yang dilakukan di kelas IV SD Negeri 004 Bangkinang Kota terdapat beberapa permasalahan dalam pembelajaran matematika khususnya di kelas IV yaitu (1) siswa mengalami kesulitan dalam menyelesaikan soal-soal matematika yang berupa soal pemecahan masalah matematika. Jika guru memberi soal yang berbeda dari contoh yang diberikan, maka sebagian besar siswa kesulitan mengerjakan, sebagian besar siswa mengeluh saat guru memberikan soal yang rumit seperti soal pemecahan masalah; (2) siswa jarang melatih kemampuan pemecahan masalah yang dimilikinya; (3) siswa ribut dalam proses pembelajaran matematika; (4) siswa pasif dalam mengikuti pembelajaran karena hanya mendengarkan materi yang disampaikan oleh guru (5) siswa tidak dapat menjawab pertanyaan dalam proses pembelajaran terlihat siswa hanya diam saja ketika diajukan pertanyaan. Adapun dalam pelaksanaan proses pembelajaran guru sudah menggunakan model dan media, namun belum maksimal dan masih belum dapat meningkatkan kemampuan pemecahan masalah matematika siswa, guru hanya memberikan rumus yang tercepat agar siswa dapat menyelesaikan soal matematika yang bersifat konsep, bukan yang bersifat soal pemecahan masalah.

Faktor-faktor yang dapat menghambat berkembangnya kemampuan pemecahan masalah matematika tersebut apabila dibiarkan, maka siswa kurang dapat mengembangkan proses berpikir kreatif, kritis dan berpikir tingkat tinggi. Selain itu siswa akan lebih sulit mengaplikasikan materi yang telah dipelajarinya. Seharusnya di dalam mengembangkan kemampuan pemecahan masalah matematika ini didasari oleh proses belajar mengajar yang mengaitkan pola kehidupan nyata siswa, dan mengaitkan pada pengetahuan yang berbeda atau yang belum diketahui siswa.

Model pembelajaran yang dapat menunjang hal tersebut, adalah model pembelajaran Problem Solving. Kegiatan pembelajarannya, siswa dituntut untuk aktif dalam menyelesaikan masalah di dalam proses pembelajaran. Model pembelajaran Problem Solving merupakan suatu model pembelajaran yang melibatkan siswa secara aktif, serta memanfaatkan representasi yang dimiliki oleh siswa. Model Problem Solving cocok untuk meningkatkan kemampuan pemecahan masalah matematika, karena model pembelajaran Problem Solving adalah suatu model pembelajaran yang memusatkan pada pengajaran dan keterampilan pemecahan masalah yang diikuti dengan penguatan keterampilan. Siswa dilatih untuk menemukan solusi dari masalah yang diberikan oleh guru secara aktif, logis, dan kreatif dengan mengikuti langkah-langkah yang telah ditentukan meliputi klarifikasi masalah, pengungkapan gagasan, evaluasi dan seleksi, serta implementasi.

Shoimin (2014 : 136) menyatakan bahwa "Model problem solving adalah salah satu model mengajar yang digunakan oleh guru dalam kegiatan proses pembelajaran. Model ini dapat menstimulasi peserta didik dalam berpikir yang dimulai dari mencari data sampai merumuskan kesimpulan sehingga peserta didik dapat mengambil makna dari kegiatan pembelajaran".

Pemecahan masalah (Problem Solving) adalah penggunaan model dalam kegiatan pembelajaran dengan jalan melatih peserta didik menghadapi berbagai masalah baik itu masalah pribadi atau perorangan maupun masalah kelompok untuk dipecahkan sendiri atau secara bersama-sama (Marta Rusdial, 2017). Proses pembelajarannya 
siswa menggunakan segenap pemikiran, memilih strategi pemecahannya, dan memproses hingga menemukan penyelesaian dari suatu pemecahan masalah.

Model pemecahan masalah (Problem Solving) adalah penggunaan model dalam kegiatan pembelajaran dengan jalan melatih siswa menghadapi berbagai masalah baik itu masalah pribadi atau perorangan maupun masalah kelompok untuk dipecahkan sendiri atau secara bersama-sama (Ahmadi: 2013:55).

Adapun rumusan masalah pada penelitian ini adalah apakah model pembelajaran Problem Solving dapat meningkatkan kemampuan pemecahan masalah matematika siswa kelas IV SD Negeri 004 Bangkinang kota?.

Sesuai dengan rumusan masalah di atas, maka tujuan penelitian ini adalah untuk mendeskripsikan peningkatan kemampuan pemecahan masalah matematika dengan menerapkan model pembelajaran Problem Solving kelas IV SD Negeri 004 Bangkinang Kota.

\section{METODOLOGI PENELITIAN}

Menurut Aqib (2011: 3) PTK adalah penelitian yang dilakukan oleh guru di kelasnya sendiri melalui refleksi diri dengan tujuan untuk memperbaiki kinerjanya sehingga hasil belajar siswanya meningkat. Sedangkan menurut Kusumah (2012: 8) PTK adalah bentuk penelitian reflektif yang dilakukan oleh guru sendiri yang hasilnya dapat dimanfaatkan sebagai alat untuk pengembangan keahlian mengajar. Jenis penelitian ini adalah Penelitian Tindakan Kelas (PTK). Penelitian ini dilaksanakan di kelas IV SDN 004 Bangkinang Kota, Kab. Kampar. Subjek penelitian ini adalah siswa kelas IV SDN 004 Bangkinang Kota tahun ajaran 2019/2020 dengan jumlah siswanya 12 orang, yang terdiri dari 6 orang siswa laki-laki dan 6 orang siswa perempuan.
Adapun yang menjadi subjek dalam penelitian ini adalah siswa kelas IV SD Negeri 004 Bangkinang Kota sebanyak 12 orang siswa yang terdiri dari 6 orang laki-laki dan 6 orang perempuan. Sedangkan objeknya adalah kemampuan pemecahan masalah matematika siswa kelas IV SDN 004 Bangkinang Kota. Penelitian tindakan kelas ini dilaksanakan dua siklus.

Instrumen penelitian adalah alat atau fasilitas yang digunakan peneliti dalam mengumpulkan data agar pekerjaaannya lebih mudah dan hasilnya lebih baik, dalam arti lebih cermat, lengkap dan sistematis sehingga lebih mudah diolah. Agar penelitian ini dapat dilaksanakan dengan baik maka perlu dipersiapkan instrument penelitian. Adapun instrument penelitian yang perlu dipersiapkan sebagai berikut:

1. Lembar Observasi

Lembar observasi tentang aktivitas guru dan siswa, pada saat pelaksanaan penelitian ini mengacu kepada penerangan model pembelajaran Problem Solving digunakan untuk memperoleh data tentang aktivitas guru dan siswa selama proses pembelajaran.

2. Lembar Tes

Adapun lembar tes yang digunakan dalam penelitian berupa butir soal yang dilakukan setelah melakukan proses pembelajaran yang diperlukan untuk mendapatkan data tentang pemecahan masalah matematis yang berisi tentang soal berdasarkan indikator yang akan dicapai sehingga kualitas pemecahan masalah matematika di ketahui.

3. Lembar Dokumentasi

Lembar dokumentasi ini digunakan untuk melihat kelengkapan data yang digunakan dalam proses pembelajaran dan kegiatan penelitian berupa foto-foto, Silabus, rencana pelaksanaan pembelajaran (RPP).

Teknik pengumpulan data merupakan langkah yang paling strategis 
dalam penelitian karena tujuan utama dari penelitian adalah untuk mendapatkan data. Adapun teknik pengumpulan data yang akan diambil sebagai berikut:

1. Tes

Tes kemampuan pemecahan masalah dilakukan dengan cara siswa mengerjakakan soal pemecahan masalah matematika yang sesuai dengan materi pelajaran, dengan tujuan untuk mengetahui seberapa besar siswa menguasai pelajaran. Cara mengumpulkan tes yaitu dengan cara mengumpulkan hasil jawaban peserta didik.

2. Observasi

Observasi dilakukan untuk mengamati aktivitas guru dan siswa selama pembelajaran berlangsung yang menerapkan model pembelajaran problem solving dengan cara mengisi kolom lembar aktivitas guru dan aktivitas siswa dengan menggunakan metode check list $(\sqrt{ })$.

3. Dokumentasi

Dokumentasi dilakukan dengan mengumpulkan data-data mengenai profil sekolah, data guru, data siswa serta sarana dan prasarana sekolah.

Analisis data yang digunakan dalam dalam penelitian ini adalah analisis data kualitatif dan kuantitatif. Analisis kualitatif digunakan untuk menganalisis lembar observasi aktivitas guru dan siswa saat proses pembelajaran. Sedangkan analisis data kuantitatif untuk menganalisis nilai kemampuan pemecahan masalah matematika siswa berikut penjelasannya:

1. Analisis Kuantitatif

a. Analisis Kemampuan Pemecahan Masalah

Untuk mengetahui kemampuan pemecahan masalah matematika melalui pembelajaran yang menerapkan model pembelajaran Problem Solving dapat dihitung dengan menggunakan rumus sebagai berikut:

$\mathrm{P}=\frac{\sum \text { Skor yang diperoleh siswa }}{\text { skor maksimal }} \times 100$

Keterangan :

$\mathrm{P}=$ Nilai akhir.

Tabel 3.2

Interval Kategori Kemampuan Pemecahan Masalah

\begin{tabular}{|c|c|}
\hline $\begin{array}{c}\text { Persentase } \\
\text { Interval }\end{array}$ & Kategori \\
\hline $90-100$ & Sangat baik \\
\hline $80-89$ & Baik \\
\hline $70-79$ & Cukup \\
\hline $60-69$ & Kurang \\
\hline$<60$ & Sangat kurang \\
\hline
\end{tabular}

Sumber: (Mawaddah \& Anisah, 2015)

b. Ketuntasan Klasikal

Jika ketuntasan klasikal siswa telah mencapai $80 \%$ dari seluruh siswa, maka secara klasikal telah tercapai dengan baik (wardhani, 2007: 25). Untuk menentukan ketuntasan klasikal, rumus yang digunakan sebagai berikut:

$\mathrm{KK}=\frac{\text { Jumlah } \text { siswa } \text { yang tuntas }}{\text { Jumlah seluruh } \text { siswa }} \times 100 \%$

Keterangan:

$\mathrm{KK}=$ Ketuntasan Klasikal

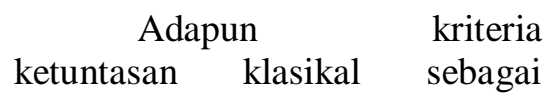

berikut:

Tabel 3.3

Interval Kategori Kriteria

Ketuntasan Klasikal

\begin{tabular}{|c|c|}
\hline $\begin{array}{c}\text { Persentase } \\
\text { Interval }\end{array}$ & Kategori \\
\hline $90-100 \%$ & Sangat Baik \\
\hline $80-89 \%$ & Baik \\
\hline $70-79 \%$ & Cukup \\
\hline $60-69 \%$ & Kurang \\
\hline$<60 \%$ & Sangat Kurang \\
\hline
\end{tabular}

Sumber: Wardhani (2007: 40)

HASIL PENELITIAN

DAN

PEMBAHASAN

A. Deskripsi Tindakan 
Sebelum
dindakan, peneliti melakukan observasi yaitu untuk mengetahui kemampuan pemecahan masalah matematika siswa. Data dari yang dilakukan dengan guru kelas IV SDN 004 Bangkinang Kota bahwa kemampuan pemecahan masalah matematika siswa masih rendah dan masih belum sesuai dengan yang diharapkan.

Berdasarkan data nilai kemampuan pemecahan masalag matematika siswa yang di peroleh dari pre test peneliti menganalisis data tersebut dengan KKM 70, dari 12 orang siswa hanya 3 orang siswa (25\%) orang yang mencapai KKM. Sedangkan siswa yang tidak mencapai KKM sebanyak 9 orang siswa $(75 \%)$.

B. Deskripsi Hasil Tindakan Tiap Siklus

Perbandingan kemampuan pemecahan masalah matematika dengan menggunakan model Problem Solving kelas IV di SDN 004 Bangkinang Kota pada siklus I dan siklus II terdapatnya peningkatan pada kemampuan pemecahan masalah matematika dengan menggunakan model Problem Solving kelas IV SDN 004 Bangkinang kota.

Diketahui bahwa nilai ratarata siswa pada siklus I pertemuan 1 sebesar 63,5 dengan kategori kurang (60-69) dan meningkat pada pertemuan 2 sebesar 70,16 dengan kategori cukup (70-79). Kemudian pada siklus II pertemuan 1 mengalami peningkatan menjadi 76,00 dengan kategori cukup (70-79). Lalu meningkat lagi pada pertemuan 2 menjadi 84,66 dengan kategori baik (80-89). Sedangkan presentase ketuntasan klasikal kemampuan pemecahan masalah matematika pada siklus I pertemuan 1 sebesar 33,33\% dengan kategori kurang sekali
(<60\%) dan pertemuan 2 meningkat menjadi $58,33 \%$ dengan kategori kurang sekali (60\%). Pada siklus II pertemuan 1 meningkat menjadi $75 \%$ dengan kategori cukup (70\%-79\%). Kemudian meningkat lagi pada pertemuan 2 sebesar $83,33 \%$ dengan kategori baik (80\%-89\%).

Untuk mengetahui secara jelas peningkatan setiap tindakan dapat dilihat pada diagram dibawah ini :

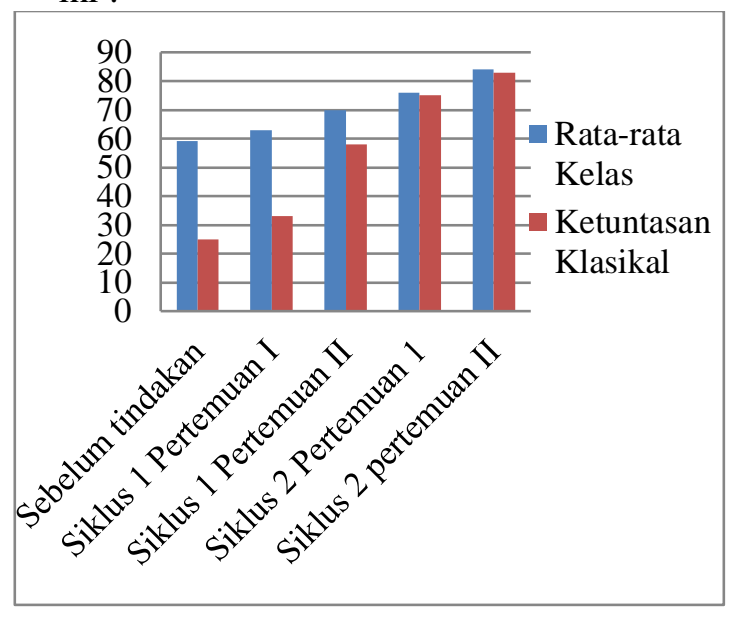

Gambar 4.1

(Diagram Perbandingan Nilai Siswa Pratindakan, Siklus I dan Siklus II)

Dilihat dari diagram di atas, dapat dilihat hasil kemampuan pemecahan masalah matematika baik secara klasikal maupun secara nilai ratarata yang diperoleh siswa mengalami peningkatan.

Berdasarkan dari hasil penelitian yang telah dilakukan, maka beberapa hal yang akan dibahas terkait penelitian ini adalah:

Sebagaimana telah diuraikan diatas menjelaskan bahwa dengan menggunakan model pembelajaran Problem Solving secara benar maka kemampuan pemecahan masalah matematika siswa menjadi lebih aktif atau baik.

Diperoleh hasil di atas dikarenakan dalam pembelajaran menggunakan model Problem Solving, siswa berperan aktif dalam proses 
pembelajaran dan secara kreatif berusaha menemukan solusi dari permasalahan yang diajukan, saling berinteraksi dengan teman maupun guru, saling bertukar pikiran, sehingga wawasan dan daya pikir mereka berkembang. Hal ini akan banyak membantu siswa dalam mningkatkan kemampuan pemecahan masalah matematika, sehingga ketika mereka dihadapkan dengan suatu pertanyaan, mereka dapat melakukan keterampilan memecahkan masalah untuj memilih dan mengembangkan tanggapannya tidak hanya dengan cara menghafal tanpa memmperdalam dan memperluaskan pemikirannya.

Berdasarkan data-data tersebut, peneliti menyimpulkan bahwa pelaksanaan pembelajaran pada siklus 1 masih belum berhasil. Untuk itu peneliti dan observer melaksanakan tindakan pada siklus berikutnya dengan melakukan refleksi, kekurangankekurangan yang muncul pada siklus 1 akan diperbaiki pada siklus berikutnya yaitu siklus II. Pada siklus II, kemampuan pemecahan masalah matematika siswa dalam proses pembelajaran dengan model pembelajaran Problem Solving berjalan dengan sangat baik. Hal itu dapat dibuktikan pada siklus II kemampuan pemecahan masalah matematika siswa mengalami peningkatan yaitu mencapai $80 \%$ yang termasuk dalam kategori tuntas karena sudah memenuhi kriteria ketuntasan minimal.

Penelitian ini masih ada 2 siswa yang masih belum paham tentang menyelesaikan soal pemecahan masalah matematika, terbukti dengan masih adanya nilai siswa yang belum tuntas, ini disebabkan karena siswa tersebut belum dapat memahami operasi hitung. Itulah sebabnya guru harus melatih kemampuan siswa dalam menyelesaikan suatu perhitungan, memperbaki dan menyempurnakan pengetahuan para siswa sebelum membahas materi baru.
Peneliti menyimpulkan bahwa pelaksanaan pembelajaran pada siklus II sudah dikatakan berhasil. Oleh karena itu, peneliti menyudahi pelaksanaan tindakan hanya smpai pada siklus II. Secara keseluruhan penerapan model pembelajaran Problem Solving untuk meningkatkan kemampuan pemecahan masalah matematika siswa kelas IV SD Negeri 004 Bangkinang Kota telah mencapai titik keberhasilan. Keberhasilan pelajaran matematika siswa kelas IV SD Negeri 004 Bangkinang Kota ditandai dengan adanya peningkatan dan perubahan pada setiap siklus

\section{SIMPULAN}

Berdasarkan hasil penelitian yang telah dilakukan peneliti dengan penerapan model pembelajaran Problem Solving untuk meningkatkan kemampuan pemecahan masalah matematika siswa kelas IV SD Negeri 004 Bangkinang Kota tahun ajaran 2019/2020 dapat disimpulkan sebagai berikut:

1. Model pembelajaran Problem Solving dapat meningkatkan kemampuan pemecahan masalah matematika siswa kelas IV SD Negeri 004 Bangkinang Kota berjalan dengan baik dapat dilihat dari hasil tes. Hasil tes pada siklus 1 pertemuan I menunjukkan ada 4 orang siswa $(33,33 \%)$ dari 12 siswa yang termasuk tuntas dengan kategori sangat kurang $(<60)$, dan pada siklus 1 pertemuan II menunjukkan ada 7 orang siswa ( $58,33 \%$ ) dari 12 siswa yang termasuk tuntas dengan kategori cukup (70$79 \%$ ), sedangkan pada siklus 2 pertemuan 1 menunjukkan ada 9 orang siswa $(75 \%)$ dari 12 orang siswa yang termasuk tuntas dengan kategori cukup (70-79\%), dan pada siklus 2 pertemuan II menunjukkan ada 10 orang siswa $(83,33 \%)$ dari 12 orang siswa yang termasuk tuntas dalam kategori baik (80-89\%). 
2. Proses meningkatkan kemampuan pemecahan masalah matematika siswa SD Negeri 004 Bangkinang Kota dengan model pembelajaran Problem Solving yaitu, a) siswa dilibatkan secara langsung dengan soal cerita, kemudian mencari datadata yang diketahui dan data yang ditanyakan, serta menyajikan masalah secara sistematis, b) siswa menemukan solusi dari masalah serta menghubungkan data yang ditanyakan dan memilih konsep, rumus, atau strategi yang akan digunakan, c) siswa dapat menyelesaikan model matematika meliputi kemampuan pengerjaan dan perhitungan serta kemampuan mengembangkan rumus atau strategi yang dipilih, d) siswa dapat dan mampu menafsirkan solusi, yaitu memeriksa kembali jawaban yang didapat dan menarik kesimpulan atas jawaban tersebut.

Berdasarkan hasil penelitian di atas, maka saran peneliti yang berhubungan dengan penelitian ini adalah sebagai berikut:

1. Bagi Guru

Hendaknya memiliki sikap inovatif dalam proses belajar mengajar sehingga siswa akan tertarik untuk mengikut pembelajaran. Selain itu guru hendaknya menggunakan berbagai pendekatan pembelajaran dalam mengajar. Salah satunya menggunakan model pembelajaran Problem Solving untuk memperbaiki kemampuan pemecahan masalah matematika di kelas.

\section{Bagi Siswa}

$$
\text { Siswa sebaiknya }
$$

mengulang materi yang dipelajari di kelas ketika telah berada di rumah, agar dapat menguasai dengan baik apa yang telah dipelajari. Diharapkan siswa dapat memperhatikan guru menyampaikan materi pembelajaran lebih baik lagi, agar apa yang disampaikan guru dapat dimengerti dengan baik.

3. Bagi Peneliti Selanjutnya

Penelitian ini diharapkan mampu menjadi menjadi referensi bagi peneliti selanjutnya untuk mengembangkan model pembelajaran Problem Solving di sekolah-sekolah dasar lainnya sehingga dapat meningkatkan kemampuan pemecahan masalah matematika.

\section{DAFTAR PUSTAKA}

Ahmadi, A. (2013). Strategi Belajar Mengajar. Bandung: Pustaka Setia

Aqib, Z. (2011). Penelitian Tindakan Kelas. Bandung: Yrama Widya.

Asmariana, A.H. (2013). Pendekatan

Keterampilan Metakognitif

Untuk Meningkatkan

Kemampuan Pemecahan

Masalah matematis Siswa SD.

(Skripsi). Sekolah Sarjana,

Universitas Pendidikan

Indonesia, Bandung.

Ismawati D.Y. (2014). Perbedaan

Kemampuan Pemecahan

Masalah Matematis Siswa

Menggunakan Pendekatan

Diskursif Metode Two Stay Two

Stray Dengan Pembelajaran

Konvensional. (Skripsi).

Sekolah Sarjana, Universitas

Pendidikan Indonesia, Bandung.

Kusumah, W. (2012). Penelitian

Tindakan Kelas. Jakarta: PT

Indeks.

Marta Rusdial. (2017). Peningkatan

Hasil Belajar Matematika

Dengan Pendekatan Problem

Solving Siswa Sekolah Dasar.

Journal Cendekia:Jurnal

Pendidikan Matematika.

Mawaddah, S., \& Anisah, H. (2015).

Kemampuan Pemecahan

Masalah Matematis Siswa Pada 
Pembelajaran Matematika dengan Menggunakag) di SMPn Model Pembelajaran Generatif (Generative Learning) di SMP. EDU-MAT: Jurnal Pendidikan Matematika.

https://doi.org/10.20527/edumat. v3i2.644

Shoimin, A. (2014). 68 Model Pembelajaran Inovatif dalam Kurikulum 2013. Yogyakarta: Ar-Ruzz Media.

Wardhani. (2007). Penelitian Tindakan Kelas. Jakarta: Universitas Terbuka. 